\title{
DASAR PERTIMBANGAN HAKIM TERHADAP PUTUSAN PERCERAIAN DENGAN PEMBERIAN HAK ASUH ANAK KEPADA BAPAK
}

\author{
Renita Ivana \\ E-mail: renitaivana97@gmail.com \\ Mahasiswa Fakultas Hukum Universitas Sebelas Maret \\ Diana Tantri Cahyaningsih \\ E-mail: dianatantri@yahoo,com \\ Dosen Fakultas Hukum Universitas Sebelas Maret
}

\begin{abstract}
This article aims to find out the basis of the judge's consideration of the Divorce Decision with the Provision of Child Custody to the father. This writing also includes normative legal research that is prescriptive. The research approach uses the Law approach (state approach) and case approach. Legal material collection techniques use legal material collection techniques with the study of documents or library materials (library study). The results of the study explained that judges' consideration arose from the six divorce decisions that the authors examined was by prioritizing the best interests principle for children, the judge giving custody of underage children to the father. This is not in accordance with the rules of the invitation that apply because the child under the age of custody is in the hands of the mother. But because of the bad behavior of the mother, abandoning the child, forgetting her responsibilities as a mother which is all the basis of the judge's consideration in making decisions regarding the granting of custody of minors to the father.
\end{abstract}

Keywords: Divorce; Consideration of Judges; Child Custody

\begin{abstract}
Abstrak
Artikel ini bertujuan untuk mengetahui dasar pertimbangan hakim terhadap Putusan Perceraian dengan Pemberian Hak Asuh Anak kepada bapak. Penelitian hukum ini merupakan penelitian hukum normatif yang bersifat preskriptif. Pendekatan penelitian menggunakan pendekatan Undang-undang (state approach) dan pendekatan kasus (case approach). Teknik pengumpulan bahan hukum menggunakan teknik pengumpulan bahan hukum dengan studi dokumen atau bahan pustaka (library study). Hasil penelitian menjelaskan bahwa pertimbangan hakim yang muncul dari keenam Putusan Perceraian yang penulis teliti adalah dengan mengedepankan asas kepentingan terbaik bagi anak, hakim memberikan hak asuh anak di bawah umur kepada bapak. Hal tersebut tidak sesuai aturan Perundang-undangan yang berlaku karena anak di bawah umur kedudukan hak asuhnya berada di tangan ibu. Namun karena perilaku ibu yang buruk, menelantarkan anak, melupakan tanggung jawabnya sebagai ibu. Sehingga menjadi dasar pertimbangan hakim dalam menjatuhkan putusan mengenai pemberian hak asuh anak di bawah umur kepada bapak.
\end{abstract}

Kata Kunci: Perceraian; Pertimbangan Hakim; Hak Asuh Anak

\section{A. Pendahuluan}

Manusia adalah makhluk sosial dimana antara manusia satu dengan manusia lain saling membutuhkan (Dahlan Hasyim, 2004:300). Bisa dikatakan bahwa manusia itu tidak bisa hidup sendiri, oleh karena itu dikenal dengan adanya hidup berpasang-pasangan yakni suatu perkawinan. Perkawinan adalah tuntutan kodrat hidup dengan tujuan untuk memperoleh keturunan, guna melangsungkan kehidupan sejenis (Ahmad Azhar Basyir, 2007:12). Dan suatu hal yang utama dari sebuah perkawinan adalah penyempurnaan ibadah kepada Tuhan Yang Maha Esa (Ginting TE dan Westra IK, 2018:2). 
Adanya perkawinan maka terbentuklah suatu keluarga, berbicara mengenai hukum keluarga maka tidak terlepas dari persoalan hukum perkawinan sebab keluarga sendiri terbentuk melalui perkawinan dan terjadilah hubungan hukum antara suami dan isteri (Tengku Erwinsyahbana, 2012:168). Muderis Zaini berpendapat bahwa keluarga mempunyai peranan penting dalam kehidupan manusia sosial dan merupakan masyarakat kecil yang terdiri dari seorang ayah, ibu dan anak (Muderis Zain, 2002:7). Menurut Soetojo Prawiromidjojo, bahwa sebuah perkawinan adalah untuk memperoleh keturunan, membentuk dan mengatur rumah tangga atas dasar cinta dan kasih sayang. Namun dalam perjalanan apabila tujuan tersebut tidak dapat diwujudkan maka akan berakhir pada perceraian (D.Y. Witanto, 2012:2).

Perceraian merupakan malapetaka yang rentan terjadi dalam sebuah perkawinan, namun jika perceraian itu terjadi kedua belah pihak harus mengusahakan agar tidak timbul malapetaka lain yang lebih berat bahayanya (Rahmadi Indra Tektona, 2012:22). Dalam Islam, perkawinan tidak terikat dalam ikatan mati dan tidak pula mempermudah terjadinya suatu perceraian. Perceraian baru boleh dilakukan jika benar-benar dalam kondisi yang darurat dan terpaksa, sebagai solusi akhir dalam menyelesaikan masalah rumah tangga (Mohammad Hifni, 2016:51). Karena perceraian timbul sebagai salah satu akibat dari tidak harmonisnya hubungan antara suami dan isteri dalam rangka menjalankan hak dan kewajibannya di dalam sebuah keluarga. Hal tersebut merupakan salah satu langkah yang diambil oleh pasangan suami isteri dalam menyelesaikan masalah rumah tangganya yang sudah tidak dapat lagi terselesaikan atau didamaikan. Perceraian itu sendiri berpangkal pada perselisihan antara suami dan isteri. Salah satu pihak menghendaki perceraian, oleh karena pihak yang lain berbuat sesuatu yang menyebabkan hubungan keluarga goyang ( $R$. Soetojo Prawirohamidjojo dan Asis Sarioedin, 2008:104).

Saat semua upaya dikerahkan untuk menyelamatkan suatu perkawinan ternyata pada akhirnya diputus cerai oleh pengadilan. Dengan putusnya suatu perkawinan berdasarkan putusan pengadilan yang telah berkekuatan hukum tetap (inkracht van gewijsde), maka akan ada akibat hukum yang mengikutinya, salah satunya adalah mengenai hak asuh atas anak yang lahir dari perkawinan tersebut. Dari hubungan dengan orang tua dan anak yang masih di bawah umur timbul hak dan kewajiban. Pemeliharaan anak pada dasarnya menjadi tanggung jawab kedua orang tua dalam hal ini meliputi masalah ekonomi, pendidikan dan segala hal mengenai kebutuhan pokok.

Dampak negatif yang paling sering terjadi ialah anak-anak yang mengalami perceraian orang tua dalam keluarganya akan memiliki pandangan negatif terhadap pernikahan, mereka akan merasa takut mencari pasangan hidupnya, takut menikah sebab merasa dibayang-bayangi kekhawatiran jika perceraian itu juga terjadi pada dirinya (Putri Rosalia, 2013:16). Bahkan beberapa anak tidak bisa terbebas dari dampak perceraian orang tuanya, seperti perasaan terluka, marah, terabaikan, dan tidak dicintai terus menetap di hati mereka bahkan hingga mereka dewasa (Kelly Cole, 2009:3). Hal ini sebagai salah satu pemicu munculnya kasus-kasus neotik, tingkah laku asusila dan kebiasaan delinkuen (Kartini Kartono, 2002:12). Saat perceraian terjadi kedua orang tua akan timbul permasalahan mengenai perebutan hak asuh anak. Apabila hal demikian ini terjadi maka Putusan Pengadilan dapat menentukan siapakah yang lebih berhak menjadi wali dari si anak tersebut. Dalam suatu perkawinan, terdapat ajaran-ajaran tentang hak dan kewajiban antara suami dan isteri. Hak-hak dan kewajiban-kewajiban demikian timbul sebagai akibat dari dilangsungkannya suatu perkawinan. Suami memiliki hak dan kewajiban atas isterinya, demikian pula isteri, memiliki hak dan kewajiban terhadap suami. Kewajiban itu salah satunya adalah menyangkut kedudukan suami sebagai kepala keluarga dan isteri sebagai ibu rumah tangga. Penegasan suami menjadi kepala keluarga sedangkan isteri menjadi ibu rumah tangga itu sebagaimana tercantum dalam Pasal 31 Ayat (3) Undang-Undang Nomor 1 Tahun 1974 tentang Perkawinan menyatakan: "Suami adalah kepala keluarga dan isteri ibu rumah tangga." Diperkuat lagi dalam Pasal 34 UndangUndang Nomor 1 Tahun 1974 tentang Perkawinan:

1. Suami wajib melindungi isterinya dan memberikan segala sesuatu keperluan hidup berumah tangga sesuai dengan kemampuannya;

2. Isteri wajib mengatur urusan rumah tangga sebaik-baiknya; 
3. Jika suami atau isteri melalaikan kewajibannya masing-masing pihak dapat mengajukan gugatan kepada Pengadilan.

Keberadaan lembaga perceraian guna mencegah kerusakan lebih parah dari kedua pasangan tersebut dan menghindarkan kerugian yang lebih besar. Sebagaimana halnya dalam perkawinan, turut timbul akibat-akibat hukum tertentu, segala akibat hukum putusnya perkawinan karena perceraian, diantaranya yaitu akibat hukum berkaitan dengan pemberian nafkah kepada isteri sebenarnya sudah diantisipasi oleh Undang-Undang Nomor 1 Tahun 1974 tentang Perkawinan dimana dalam Pasal 41 dinyatakan bahwa akibat putusnya perkawinan karena perceraian ialah:

a. Baik ibu atau bapak tetap berkewajiban memelihara dan mendidik anak-anaknya, sematamata berdasarkan kepentingan anak, bilamana ada perselisihan mengenai penguasaan anakanak Pengadilan memberi keputusannya;

b. Bapak yang bertanggung jawab atas semua biaya pemeliharaan dan pendidikan yang diperlukan anak itu; bilamana bapak dalam kenyataannya tidak dapat memenuhi kewajiban tersebut, Pengadilan dapat menentukan bahwa ibu ikut memikul biaya tersebut;

c. Pengadilan dapat mewajibkan kepada mantan suami untuk memberikan biaya penghidupan dan/atau menentukan sesuatu kewajiban bagi mantan isteri.

Perceraian bukanlah halangan bagi anak untuk memperoleh hak pengasuhan atas dirinya dari kedua orang tuanya, ketika perceraian terjadi anak akan menjadi korban utama. Sekarang sudah ada konsensus yang kuat dalam literatur penelitian bahwa anak-anak yang orang tuanya telah bercerai pada peningkatan risiko menampilkan berbagai masalah perilaku dibandingkan dengan anak yang hidup dalam keluarga terus utuh (Nilgun Ongider, 2013:140). Orang tua adalah orang pertama yang bertanggung jawab untuk membayarkan hak-hak anak keturunan mereka, namun tidak jarang tugas seperti itu menjadi terputus baik atas kehendak suami isteri, maupun di luar kehendak mereka. Hal ini menyangkut dengan aspek kesejahteraan anak agar dapat tumbuh dan berkembang menjadi penerus yang dapat diharapkan sebagai tiang dan pondasi orang tua, keluarga, masyarakat, bangsa dan negara. Pengasuhan anaklah yang menjadi kunci atas masa depan si anak tersebut, hal ini menjadi kewajiban dan tanggung jawab orang tua di lingkungan keluarga tetapi demi untuk kepentingan kelangsungan tatasosial maupun untuk kepentingan anak itu sendiri, dibutuhkan pihak lain untuk melindunginnya. Apabila orang tua sudah tidak diketahui adanya atau pada kenyataannya tidak mampu untuk melaksanakan hak dan kewajibannya, maka pihak lain dapat diserahi hak dan kewajiban itu baik dengan kehendak sendiri maupun dengan ketentuan hukum (Abdussalam, 2007:24). Setelah bercerainya kedua orang tua tentunya akan adanya hak hadhanah terhadap si anak baik kepada si ibu maupun bapaknya berdasarkan keputusan yang telah ditetapkan oleh hakim.

Dewasa ini suatu perceraian dianggap suatu hal yang biasa, karena banyak orang yang melakukan perkawinan kemudian selang beberapa waktu bercerai padahal dari hasil perkawinan tersebut sudah dikaruniai anak. Dalam Undang-Undang Perkawinan memang belum ada Pasal yang menjelaskan mengenai hak asuh anak setelah cerai akan jatuh kepada ibu atau bapak. Hak asuh anak di bawah umur biasanya jatuh kepada ibu karena dianggap ibu lah yang berhak, hal tersebut termuat dalam Pasal 105 Kompilasi Hukum Islam Tahun 1991 dan Putusan Mahkamah Agung Republik Indonesia Nomor: 126K/Pdt/2001 tanggal 28 Agustus 2003 serta Putusan Mahkamah Agung Republik Indonesia Nomor 102K/Sip/1973 tanggal 24 April 1975. Namun dalam kondisi tertentu aturan tersebut tidak berlaku, ada 6 (enam) Putusan Pengadilan mengenai pemberian hak asuh anak di bawah umur kepada bapak seperti yang akan penulis teliti yaitu Putusan Nomor 906/ Pdt.G/2012/PN.SBY, Putusan Nomor 278/Pdt.G/2016/PN.Dps, Putusan Nomor 527/Pdt.G/2012/ PN.Dps, Putusan Nomor 1654/Pdt.G/2013/PA.Jbg, Putusan Nomor 335/Pdt.G/2014/PA.Clg dan Putusan Nomor 574K/Ag/2016.

Keenam putusan tersebut Hakim memberikan pertimbangannya dalam hal memberikan pengasuhan anak di bawah umur kepada bapak. Dasar pertimbangan hakim terhadap keenam putusan perceraian yang penulis teliti ialah dikarenakan perilaku ibu yang buruk dan melepas 
kewajibannya sebagai orang tua, sehingga asas kepentingan terbaik bagi anak tidak terlaksana namun ada hal menarik yang penulis dapatkan untuk membedakan dasar pertimbangan hakim dalam keenam putusan tersebut. Misalnya karena faktor agama, faktor budaya dan faktor adat. Terdapat penekanan-penekanan di faktor utama yang menyebabkan hakim memilih bapak sebagai pengasuh anak di bawah umur. Berdasarkan penulisan tersebut, penulis ingin mengkaji mengenai pertimbangan Hakim yang terhadap pemberian hak asuh anak di bawah umur kepada bapak.

\section{B. Metode Penelitian}

Jenis penelitian yang penulis gunakan dalam menyusun penelitian ini adalah penelitian hukum normatif yang bersifat perspektif serta penulis menggunakan pendekatan undang-undang (statute approach) dan pendekatan kasus. Bahan hukum primer yang penulis gunakan dalam penelitian ini adalah peraturan perundang-undangan, dan Putusan Nomor: 906/Pdt.G/2012/PN.SBY, Putusan Nomor Nomor: 278/Pdt.P/2016/PN.Dps, Putusan Nomor: 527/Pdt.G/2012/PN. Dps, Putusan Nomor: 1654/Pdt.G/2013/PA.Jbg, Putusan Nomor: 574 K/Ag/2016, Putusan Nomor: 335/ Pdt.G/2014/PA.Clg kemudian bahan hukum sekunder yang penulis gunakan adalah buku-buku, jurnal hukum, skripsi atau thesis, artikel hukum dan bahan hukum lain yang diperoleh melalui media sosial dan internet yang masih relevan dengan penelitian hukum ini. Teknik pengumpulan bahan hukum menggunakan teknik studi pustaka.

\section{Hasil Penelitian dan Pembahasan}

Berdasarkan bahan hukum dan kajian yang telah dilakukan oleh penulis mengenai pertimbangan hakim yang memberikan hak asuh anak di bawah umur kepada bapak ialah dengan memfokuskan pada asas kepentingan terbaik bagi anak, seperti yang ada dalam 6 (enam) putusan pengadilan antara lain sebagai berikut:

\section{Pertimbangan Hakim Putusan Nomor: 906/Pdt.G/2012/PN.SBY}

Menimbang bahwa sering terjadi percekcokan yang disebabkan oleh tergugat karena sering meninggalkan rumah pulang hingga larut malam tanpa seijin penggugat. Bahwa tergugat lebih mementingkan kepentingan pribadi tanpa peduli dengan keberadaan anaknya. Bahwa tergugat seolah-olah melupakan kewajibannya sebagai ibu terhadap anak dan suaminya. Bahwa tergugat telah pergi meninggalkan anaknya 2 hari setelah ulang tahun 1 anaknya kepada penggugat hingga saat ini. Bahwa tergugat hanya menengok anaknya sebanyak 2 kali setelah meninggalkan anaknya kepada penggugat dan tidak kembali lagi. Bahwa selama ini yang membiayai dan mengurus anak adalah penggugat. Bahwa tergugat tidak memiliki pekerjaan yang tetap. Bahwa penggugat sangat sayang dan memberikan perhatian penuh kepada anaknya.

Berdasarkan Putusan Nomor: 906/Pdt.G/2012/PN.SBY tersebut, pertimbangan hakim telah sesuai dengan peraturan perundang-undangan. Pasal 105 huruf (a) Kompilasi Hukum Islam menyebutkan bahwa batas mumayyiz seorang anak adalah berumur 12 tahun dan pemeliharaan anak yang belum berumur 12 tahun adalah hak ibunya (Abdurahman, 2007: 138), berdasarkan Pasal tersebut seharusnya hak asuh anak diberikan kepada Ibu namun terdapat beberapa keadaan yang mengakibatkan hak asuh anak dapat diberikan kepada bapak diantaranya dalam perkara ini yaitu karena ibu sering meninggalkan rumah pulang hingga larut malam, lebih mementingkan kepentingan pribadi tanpa peduli dengan keberadaan anaknya, melupakan kewajibannya sebagai ibu terhadap anak dengan meninggalkan anaknya 2 hari setelah ulang tahun, dan hanya menengok anaknya sebanyak 2 kali setelah meninggalkan anaknya dan tidak kembali lagi. Berkaitan dengan hal tersebut maka demi kemaslahatan anak, hak asuh anak dapat dijatuhkan kepada bapak sebagaimana Perlindungan Konvensi Hak Anak juga mengatakan kedua orang tua bertanggung jawab untuk menjamin perlindungan bagi anak dan pengembangan pertumbuhan bagi anaknya. Hal ini tercantum dalam Pasal 27 Ayat (2) yang menyatakan bahwa: 
"Orang tua atau mereka yang bertanggung jawab atas anak memikul tanggung jawab utama untuk menjamin, dalam batas-batas kemampuan dan keuangan mereka, kondisi kehidupan yang diperlukan bagi pengembangan anak."

Apabila kedua orang tua telah bercerai maka pengasuhan dan pemeliharaan anak tetap merupakan kewajiban dan tanggung jawab bagi orang tua, walaupun dari salah satu kedua orang tuanya memiliki hak asuh anak. Akan tetapi dalam pengasuhan dan pemeliharaan anak merupakan hak anak-anaknyalah yang lebih diutamakan demi untuk kemaslahatan anak ke depannya. Hal ini tercantum dalam Pasal 14 Undang-Undang Nomor 35 Tahun 2014 tentang Perubahan Atas Undang-Undang Nomor 23 Tahun 2002 tentang Perlindungan Anak. Maka hak asuh anak dalam perkara ini sudah tepat diberikan kepada Bapak sebagaimana isi putusan tersebut.

\section{Pertimbangan Hakim Putusan Nomor: 278/Pdt.P/2016/PN. Dps}

Berdasarkan Putusan Nomor: 278/Pdt.P/2016/PN. Dps, pertimbangan hakim telah sesuai dengan ketentuan perundang-undangan yaitu apabila kedua orang tua telah bercerai maka pengasuhan dan pemeliharaan anak tetap merupakan kewajiban dan tanggung jawab bagi orang tua, walaupun dari salah satu kedua orang tuanya memiliki hak asuh anak. Akan tetapi dalam pengasuhan dan pemeliharaan anak merupakan hak anak-anaknyalah yang lebih diutamakan demi untuk kemaslahatan anak ke depannya. Hal ini tercantum dalam Pasal 14 Undang-Undang Nomor 35 Tahun 2014 tentang Perubahan Atas Undang-Undang Nomor 23 Tahun 2002 tentang Perlindungan Anak. Berdasarkan hak tersebut berkaitan dengan perkara ini setelah terjadi perceraian hak asuh anak jatuh kepada ibu namun pada faktanya anak tersebut lebih memilih untuk tinggal bersama bapak. Ibu jarang menemui anak yang seharusnya menjadi tanggung jawabnya (dalam 6 bulan terakhir hanya 2 kali menemui). Ibu juga mempersulit anak tersebut dalam mengurus visa oleh pihak Imigrasi karena tidak mau menandatangani dalam proses pembuatan perpanjangan passport/visa, maka berdasarkan keadaan tersebut, hakim telah memberikan putusan yang sesuai dengan ketentuan perundangundangan demi kemaslahatan anak yaitu dengan memberikan hak asuh anak kepada bapak.

3. Pertimbangan Hakim Putusan Nomor: 527/Pdt.G/2012/PN. Dps

Berdasarkan Putusan Nomor: 527/Pdt.G/2012/PN.Dps tersebut, pertimbangan hakim telah sesuai dengan peraturan perundang-undangan. Sosok ibu dalam perkara ini adalah seorang wanita yang tidak berkelakuan baik (suka berbohong, berhutang dan sering meninggalkan rumah tanpa seijin Penggugat), sehingga demi kemaslahatan anak maka hak asuh dapat diberikan kepada bapak sebagaimana isi putusan ini berdasarkan ketentuan perundang-undangan yang menyatakan bahwa apabila kedua orang tua telah bercerai maka pengasuhan dan pemeliharaan anak tetap merupakan kewajiban dan tanggung jawab bagi orang tua, walaupun dari salah satu kedua orang tuanya memiliki hak asuh anak. Akan tetapi dalam pengasuhan dan pemeliharaan anak merupakan hak anak-anaknyalah yang lebih diutamakan demi untuk kemaslahatan anak ke depannya. Hal ini tercantum dalam Pasal 14 Undang-Undang Nomor 35 Tahun 2014 tentang Perubahan Atas Undang-Undang Nomor 23 Tahun 2002 tentang Perlindungan Anak.

4. Pertimbangan Hakim Putusan Nomor: 1654/Pdt.G/2013/PA.Jbg

Berdasarkan Putusan Nomor: 1654/Pdt.G/2013/PA.Jbg, pertimbangan hakim telah sesuai dengan peraturan perundang-undangan sebagaimana Pasal 14 Undang-Undang Nomor 35 Tahun 2014 tentang Perubahan Atas Undang-Undang Nomor 23 Tahun 2002 tentang Perlindungan Anak bahwa apabila kedua orang tua telah bercerai maka pengasuhan dan pemeliharaan anak tetap merupakan kewajiban dan tanggung jawab bagi orang tua, walaupun dari salah satu kedua orang tuanya memiliki hak asuh anak. Akan tetapi dalam pengasuhan dan pemeliharaan anak merupakan hak anak-anaknyalah yang lebih diutamakan demi untuk kemaslahatan anak ke depannya. Berkaitan dengan perkara tersebut karena ibu telah berpindah keyakinan dari agama Islam yang merupakan agama yang sudah dianut sejak 
menikah dan sering pergi ke luar kota sehingga demi kemaslahatan anak hak asuh diberikan kepada bapak untuk dapat menjaga tumbuh kembang anak dan menjaga aqidah anak. Hal tersebut sesuai dengan Pasal 156 KHI (Kompilasi Hukum Islam) dinyatakan;

"apabila pemegang hadhonah tidak dapat menjamin keselamatan jasmani dan rohani anak, maka Pengadilan Agama dapat memindahkan hak hadhonah......dst-nya ".

5. Pertimbangan Hakim Putusan Nomor: 574 K/Ag/2016

Berdasarkan Putusan Nomor: $574 \mathrm{~K} / \mathrm{Ag} / 2016$, pertimbangan hakim telah sesuai dengan ketentuan perundang-undangan sebagaimana Pasal 14 Undang-Undang Nomor 35 Tahun 2014 tentang Perubahan Atas Undang-Undang Nomor 23 Tahun 2002 tentang Perlindungan Anak yang menyatakan bahwa Apabila kedua orang tua telah bercerai maka pengasuhan dan pemeliharaan anak tetap merupakan kewajiban dan tanggung jawab bagi orang tua, walaupun dari salah satu kedua orang tuanya memiliki hak asuh anak. Akan tetapi dalam pengasuhan dan pemeliharaan anak merupakan hak anak-anaknyalah yang lebih diutamakan demi untuk kemaslahatan anak ke depannya. Dalam perkara ini sang ibu sering pergi keluar negeri dan anak diurus oleh asisten rumah tangganya. Sang ibu juga merupakan seorang pecandu narkoba dan sering menonton film porno dan seharusnya wajib melakukan rehabilitasi tetapi yang bersangkutan menolak. Maka berdasarkan keadaan tersebut hak asuh anak dijatuhkan kepada bapak demi kemaslahatan anak.

6. Pertimbangan Hakim Putusan Nomor: 335/Pdt.G/2014/PA.Clg

Berdasarkan Putusan Nomor: 335/Pdt.G/2014/PA.Clg., pertimbangan hakim telah sesuai dengan ketentuan perundang-undangan sebagaimana Pasal 14 Undang-Undang Nomor 35 Tahun 2014 tentang Perubahan Atas Undang-Undang Nomor 23 Tahun 2002 Tentang Perlindungan Anak yang menyatakan bahwa Apabila kedua orang tua telah bercerai maka pengasuhan dan pemeliharaan anak tetap merupakan kewajiban dan tanggung jawab bagi orang tua, walaupun dari salah satu kedua orang tuanya memiliki hak asuh anak. Akan tetapi dalam pengasuhan dan pemeliharaan anak merupakan hak anak-anaknya lah yang lebih diutamakan demi untuk kemaslahatan anak ke depannya. Berkaitan dengan perkara ini ketiga anak tersebut memilih tinggal bersama Bapak karena ibu menikah lagi setelah terjadi perceraian dan saat ini sedang hamil dan membawa anak ketiga mereka sehingga sulit ditemui oleh bapak dan kakak-kakaknya. Ibu juga sering berkata-kata dan bertindak kasar kepada Bapak sehingga anak-anaknya tidak nyaman. Berkaitan dengan hal-hal tersebut sudah sepantasnya hakim memberikan hak asuh anak kepada bapak demi kemaslahatan anak.

Sesuai dengan 6 (enam) Putusan tersebut di atas, pertimbangan hakim adalah salah satu aspek terpenting dalam menentukan terwujudnya nilai dari suatu putusan hakim yang mengandung keadilan dan kepastian hukum serta kemanfaatan bagi para pihak yang bersangkutan sehingga pertimbangan hakim ini harus disikapi dengan teliti, baik dan cermat dalam memutuskan perkara yang ada (Erisa Ardika Persada dan Andri Sapuan, 2017:37). Sehingga hakim dalam menimbang memerlukan banyak hal untuk menyatakan putusan yang seadil-adilnya untuk para pihak, pertimbangan itu sendiri tidak selalu berlandaskan hukum formal saja melainkan banyak hal yang bisa dijadikan dasar pertimbangan hakim seperti yang tertulis dalam salah satu jurnal:

"Law cannot de succcesfully separated from politics, morals, and the rest of human activities, but is an integral part of web of social life"(Olsen F, 1990:211).

Yang artinya bahwa hukum tidak akan berhasil jika dipisahkan dari politik, moral dan sisanya adalah aktivitas manusia yang merupakan bagian integral dari kehidupan sosial. Hukum bersifat responsif yaitu hukum sangat terbuka terhadap perubahan-perubahan masyarakat dengan maksud mengikuti perkembangan masyarakat sekitarnya dan mencapai sasaran-sasaran kebijakan sosial, dalam hal ini hukum bisa berasal dari mana saja sehingga saling berkesinambungan dengan tujuan menciptakan kehidupan yang laras dan sejahtera seperti halnya Hakim dalam menggunakan pertimbangannya dalam pengambilan Putusan Pengadilan. 


\section{Simpulan}

Kesimpulan dari uraian pembahasan yang telah penulis uraikan adalah sebagai berikut:

Pertimbangan Hakim terhadap 6 (enam) Putusan Perceraian dengan Pemberian Hak Asuh Anak di Bawah Umur kepada bapak tidak sesuai dengan peraturan Perundang-undangan yang berlaku karena dalam masing-masing putusan tersebut ternyata memiliki dasar pertimbangan hakim yang berbeda-beda seperti halnya kelakuan ibu yang buruk, menelantarkan anaknya, melupakan tanggung jawab sebagai ibu.

Sehingga mengakibatkan pemberian hak asuh anak akibat dari perceraian tersebut jatuh kepada bapak, termuat dalam Undang-Undang Perlindungan Anak, Undang-Undang Perkawinan dan Kompilasi Hukum Islam bahwa ibulah yang diwajibkan mendapat hak asuh anak di bawah umur tersebut. Sehingga dapat disimpulkan bahwa kelangsungan hidup dan kesejahteraan anak terutama anak di bawah umur disini sangat dikedepankan, para Hakim yang menangani kasus seperti ini tidak hanya menggunakan peraturan-peraturan formal saja seperti Undang-Undang namun juga menggunakan pertimbangan-pertimbangan lain yang mana pertimbangan tersebut bertujuan untuk memberikan penghidupan layak dan sejahtera dan hal tersebut tidak jauh-jauh dari kepentingan terbaik bagi anak.

\section{E. Saran}

1. Pemerintah Daerah seharusnya menggencarkan penyuluhan kepada masyarakat mengenai dampak negatif dari perceraian terhadap perkembangan anak, serta meminimalisir terjadinya perceraian di daerahnya dengan tidak mempermudah proses perceraian dan menjadikan mediasi sebagai salah satu faktor penting untuk membatalkan perceraian.

2. Kepada para pihak yang sudah melangsungkan perkawinan, hendaknya menjaga keutuhan rumah tangganya sehingga tercipta kehidupan keluarga yang harmonis dan sejahtera karena hal tersebut mempengaruhi tumbuh kembang anak, jika menghadapi masalah dalam rumah tangga hendaknya dihadapi secara jernih dan jangan mudah mengambil keputusan untuk bercerai karena perceraian bukanlah selalu menjadi solusi terbaik.

3. Masyarakat diharapkan memahami apa itu perkawinan, hindari melakukan pernikahan dini lebih baik mematangkan usia dan kesiapan diri jika ingin melakukan suatu perkawinan, pilihlah pasangan yang baik karena hal itu yang sangat mempengaruhi kehidupan pernikahan selamanya agar tidak terjadi hal-hal buruk dalam perkawinan yang dilakukan nantinya.

\section{F. Daftar Pustaka}

Abdullah Azzam Nur. 2017. "Hak Asuh Anak Akibat Peceraian Perspektif Hukum Islam (Studi Putusan Nomor 0503/Pdt.G/2014/PA.Yk)". Skripsi. Yogyakarta: Fakultas Syariah dan Hukum UIN Sunan Kalijaga.

Anjar S C Nugraheni, Diana Tantri C, Zeni Luthfiyah. 2013. "Komparasi Hak Asuh dan Hak Nafkah Anak dalam Putusan-Putusan Perceraian di Pengadilan Negeri dan Pengadilan Agama Kota Surakarta". Yustisia. Volume 2. Nomor 3. Surakarta: Fakultas Hukum Universitas Sebelas Maret.

Faridaziah Syahrain. 2017. "Penetapan Hak Asuh Anak di Bawah Umur Akibat Perceraian Perspektif Hukum Islam". Lex et Societatis. Volume 5. Nomor 7. Manado: Fakultas Hukum Universitas Sam Ratulangi.

Mansari. 2016. "Pertimbangan Hakim Memberikan Hak Asuh Anak kepada Ayah: Suatu Kajian Empiris di Mahkamah Syar'iyah Banda Aceh". Petita. Volume 1. Nomor 1. Banda Aceh: Fakultas Hukum Universitas Islam Negeri Ar-Raniry. 
Mansari, Reza Maulana. 2018. "Legal Certainty for Mumayiz Minors in Post-Divorce Custody an Analysis of Court Decision Number 175/PDT.G/2011/MS-BNA". Skripsi. Banda Aceh: Fakultas Hukum Universitas Islam Negeri Ar-Raniry.

Meita Djohan OE. 2016. "Hak Asuh Anak Akibat Perceraian (Studi Perkara Nomor 0679/Pdt.G/2014/PA Tnk)". Jurnal IImu Hukum. Volume 11. Nomor 1. Bandar Lampung: Fakultas Hukum Universitas Bandar Lampung.

Tria Ismina. 2018. "Penerapan Pemberian Hak Asuh Anak di bawah Umur oleh Orang Tua Laki-Laki di Pengadilan Agama Pekanbaru menurut Instruksi Presiden Nomor 1 Tahun 1991 tentang Kompilasi Hukum Islam". Jurnal Online Mahasiswa.Riau: Fakultas Hukum Universitas Riau. 